\title{
Monitoring the spatio-temporal dynamics of swidden agriculture and fallow vegetation recovery using Landsat imagery in northern Laos
}

\author{
LIAO Chenhua ${ }^{1,2}$, FENG Zhiming ${ }^{1},{ }^{*}$ LI Peng $^{1}$, ZHANG Jinghua ${ }^{1}$ \\ 1. Institute of Geographic Sciences and Natural Resources Research, CAS, Beijing 100101, China; \\ 2. University of Chinese Academy of Sciences, Beijing 100049, China
}

\begin{abstract}
Swidden agriculture is an age-old, widespread but controversial farming practice in Montane Mainland Southeast Asia (MMSEA). In the uplands of northern Laos, swidden agriculture has remained a predominant human-dominated land-use type for centuries. However, swidden system has undergone dramatic transformations since the mid-1990s. Debates on changes in swidden cultivation are linked to globally critical issues, such as land use/cover changes (LUCC), biodiversity loss and environmental degradation. Since the implementation of Reducing Emissions from Deforestation and Forest Degradation (REDD), much attention has been paid nationally and internationally to swidden agriculture in the tropics. However, knowledge of the explicitly spatial characteristics of swidden agriculture and the consequences of these transitions at macroscopic scale is surprisingly scarce. In this study, the intensity of swidden use and fallow forest recovery in northern Laos in 1990, 2002, and 2011 were delineated by means of Landsat Thematic Mapper (TM) and Enhanced Thematic Mapper plus $(\mathrm{ETM}+)$ imagery $(30 \mathrm{~m})$ using a decision tree classification approach, followed by an analysis of the spatio-temporal changes in swidden agriculture. Next, annual successive TM/ETM+ images during 2000-2010 were used to delineate the dynamics of the burning and cropping phase. Subsequently, the burned pixels identified in 2000 were compared respectively with their counterparts in the following years (2001-2011) to investigate temporal trends, land-use frequency, and the swidden cycle using time-series Landsat-based Normalized Difference Vegetation Index (NDVI) data. Finally, as the swidden cycle changed from 1 to 11 years, the fallow vegetation recovery process was studied. The results showed that: (1) from 1990 to 2011 , the area of swidden agriculture increased by $54.98 \%$, from $1.54 \times 10^{5}$ ha to $2.38 \times 10^{5}$ ha in northern Laos. The increased swidden cultivation area was mainly distributed in Luang Prabang and southern Bokeo, whereas the decreased parts were mainly found in Phongsali; (2) swidden agriculture increased mainly at elevations of $500-800 \mathrm{~m}, 300-500 \mathrm{~m}$, and $800-1000 \mathrm{~m}$ and on slopes of $10^{\circ}-20^{\circ}$ and $20^{\circ}-30^{\circ}$. Over $80 \%$ of swidden fields were
\end{abstract}

Received: $2015-01-20$ Accepted: $2015-03-02$

Foundation: National Natural Science Foundation of China, No.41301090, No.41271117; Key Program for Strategic Science and Technology, Chinese Academy of Sciences, No.2014SJCB006

Author: Liao Chenhua (1987-), PhD Candidate, specialized in resource exploitation and land use/cover change.

E-mail: liaoch.12b@igsnrr.ac.cn; yuhua_0723@126.com

"Corresponding author: Li Peng (1984-), PhD and Assistant Professor, specialized in remote sensing of natural resources, land use and cover changes, E-mail: lip@igsnrr.ac.cn

www.geogsci.com www.springerlink.com/content/1009-637x 
transformed from forests; (3) during 2000-2011, the frequency of swidden use in northern Laos was about two or three times. The interval between two successive utilization of a swidden ranged from one to seven years. Comparison of swidden cycles and the related proportions of swidden farming in 2000, 2003, and 2007 revealed that swidden cycles in most areas were shortened; and (4) there was a significant correlation (0.97) between fallow vegetation recovery and the swidden cycle. The NDVI of regenerated vegetation could approach the average level of forest when the swidden cycle reached 10 years.

Keywords: swidden agriculture; spatio-temporal changes; swidden cycle; frequency of swidden use; fallow vegetation recovery; Landsat; Laos

\section{Introduction}

Swidden agriculture, also known as slash-and-burn agriculture or shifting cultivation, is an age-old farming practice which is widespread in the tropics. There are 40-50 countries globally with almost 300-500 million people living in the mountainous and hilly parts of Latin America, Central Africa, and Southeast Asia (SEA) and directly or indirectly practicing the swidden system (Mertz, 2009; Li et al., 2014). The swidden system can be characterized as a farming system where fields are cleared by fire, cultivated for a short period (one to three years), and then left fallow for a longer period (Mertz et al., 2009; Leisz and Rasmussen, 2012). These phases of swidden system are generally called the burning/conversion phase, the cropping phase, and the fallow phase (Rerkasem et al., 2009; Li et al., 2014). In many parts of the forest-agriculture frontiers of the tropics, particularly in Southeast Asia, swidden agricultural land is rapidly being transformed to other land-use types. However, knowledge of the spatial and demographic extent of swidden cultivation and the consequences of the transitions taking place is surprisingly scarce (Mertz et al., 2009; Schmidt-Vogt et al., 2009; Padoch et al., 2007). Debates on the changes in swidden system are linked to globally important issues such as land use/cover change (LUCC), biodiversity loss, and carbon sequestration (Mertz et al., 2009; Rerkasem et al., 2009; Padoch et al., 2010; Bruun et al., 2009). Since the implementation by the United Nations of the Reducing Emissions from Deforestation and Forest Degradation (or REDD) program, much attention has been paid to swidden agriculture worldwide (Li et al., 2014; Mertz, 2009; Fox et al., 2013).

Previous studies of swidden cultivation primarily focused on observational and experimental analyses in the fields of anthropology, ethnology, and agronomy (Li et al., 2014). Field investigations of swidden agriculture were generally based on a specific plot and involved carrying out regular continuous observations (Nakano, 1978; Padoch et al., 2007), or including household surveys at village scale (Schuck et al., 2002; Rasul and Thapa, 2003). Since the 1970s, remote sensing has provided a continuous impetus to monitor the patterns and changes of tropical land use and land cover. However, many studies have underlined that swidden agriculture often fails to be identified on land-use and land-cover maps (Padoch et al., 2007; Schmidt-Vogt et al., 2009). Due to the complexity and dynamics of swidden system, with land-cover types changing from year to year, accurate mapping and delineation of swidden system is challenging (Padoch et al., 2007; Schmidt-Vogt et al., 2009). Early swidden agriculture monitoring studies supported by remote-sensing technologies began in the 1980s. In these studies, multi-source and multi-temporal satellite data were used for swidden cultivation mapping. The most commonly used data was Landsat Multi-Spectral 
Scanner (MSS), Thematic Mapper (TM), and Enhanced Thematic Mapper Plus (ETM+) imagery (Roy et al., 1985; Dwivedi and Ravi Sankar, 1991; Chowdary et al., 2012; Leisz and Rasmussen, 2012). For example, Leisz and Rasmussen (2012) mapped fallow lands in Vietnam's north-central mountainous area using yearly TM imagery and a land-cover succession model. Chowdary et al. (2012) used TM/ETM+ imagery and a supervised classification method to monitor the alternation of cropping and fallow fields and their transformation to and from forest in Oudomxay Province in northern Laos. Coarse resolution data such as Moderate-resolution Imaging Spectroradiometer (MODIS) and SPOT-4 VEGETATION data are used to study changes in swidden farming at regional and national scales (Hurni et al., 2013; Stibig et al., 2007). In the tropics, because swidden practice takes place on small plots with area less than $0.01 \mathrm{~km}^{2}$ (Siren and Brondizio, 2009), it is therefore challenging to map swidden system accurately using coarse resolution data. Therefore, studies on accurate mapping and delineation of swidden agriculture at macroscopic scale are still scarce.

The alternation of cropping and fallow phases is a dominant feature of swidden system, yet explicit knowledge of the intensity of swidden cultivation is generally lacking (Hett et al., 2012). There is a clear distinction between long-term and short-term swidden cultivation (Schmidt-Vogt, 1999). Short-term swidden cultivation with primary forest swiddening has been widely regarded as an unacceptable and destructive practice as it causes environmental degradation (Cramb et al., 2009; Fox, 2000; Achard et al., 2002; Padoch et al., 2010). Long-term swidden cultivation with secondary forest swiddening is in many cases a rationally economic and environmental choice for poor farmers in the tropics (Mertz et al., 2008; Cramb et al., 2009). Severe declines in plant diversity have been observed in SEA when swidden cultivation is replaced by permanent land-use systems (Rerkasem et al., 2009). In the humid tropics, extensive tropical secondary forests have been established by the swidden-fallow system (Coomes et al., 2000). Sovu et al. (2009) studied the species composition, structure, and diversity of secondary forests recovered on abandoned swidden cultivation fields in the lowlands of Laos in relation to 1-km distance from natural forest, fallow length, and crop-fallow rotation cycle. However, at the provincial or higher levels, the relationship between the swidden cycle and fallow forest recovery remains poorly understood.

In the uplands of northern Laos, swidden agriculture has remained a predominant land-use type for centuries. Since the mid-nineties, this traditional agricultural system has undergone dramatic transformation (Roder et al., 1997; Hurni et al., 2013). To understand the spatio-temporal dynamics of swidden system, the intensity of swidden use, and fallow forest recovery in the northern Laos, we detected swidden agriculture with TM/ETM+ imagery using a decision-tree classification approach, followed by an analysis of the transformation of swidden cultivation during 1990-2011. Next, annual successive Landsat TM/ETM+ images from 2000-2010 were used to delineate the dynamics of the burning and cropping phases. Subsequently, the burned pixels observed in 2000 were compared with their counterparts in the following years (2001-2011) under ArcGIS 10.0 to investigate temporal trends, frequency of swidden use, and the swidden cycle with time-series Landsat-based NDVI data. Finally, as the swidden cycle ranged from 1 to 11 years, fallow vegetation succession processes were studied. The main objectives of this paper are twofold: (1) mapping and delineating of the swidden system in northern Laos at a provincial scale using Landsat TM/ETM+ imagery; and (2) proposing a new method for calculating the intensity of 
swidden use in relation to the swidden cycle and swidden frequency based on ArcGIS technology.

\section{Data and methods}

\subsection{Study area}

The study area consists of five provinces in northern Laos, namely Phongsali, Luang Namtha, Oudomxay, Bokeo and Luang Prabang (Figure 1). This region adjoins southwest China and is an important part of the Great Mekong Subregion. The landscape is predominantly mountainous with the elevations ranging from 196 to $2257 \mathrm{~m}$ above sea level. Annual precipitation ranges from 1300 to $1800 \mathrm{~mm}$, averaging approximately $1240 \mathrm{~mm}$ (Thongmanivong et al., 2009). There is a clear distinction between the rainy season (May-October) and the dry season (November-April). Annual average temperature reaches a maximum of $24^{\circ} \mathrm{C}$ during June and July and a minimum of $14^{\circ} \mathrm{C}$ during December and January (Thongmanivong and Fujita, 2006). A diverse forest types consisting of tropical rainforest, monsoon forest, and low mountainous forest cover more than $80 \%$ of the region (Liu et al., 2014). With the economic upsurge and the development of road networks, upland swidden cultivation and fallow forests are undergoing rapid transformations. The total population of the five provinces is over 1.09 million, with more than one-third concentrated in Luang Prabang. The ethnic composition of northern Laos is characterized by high diversity.

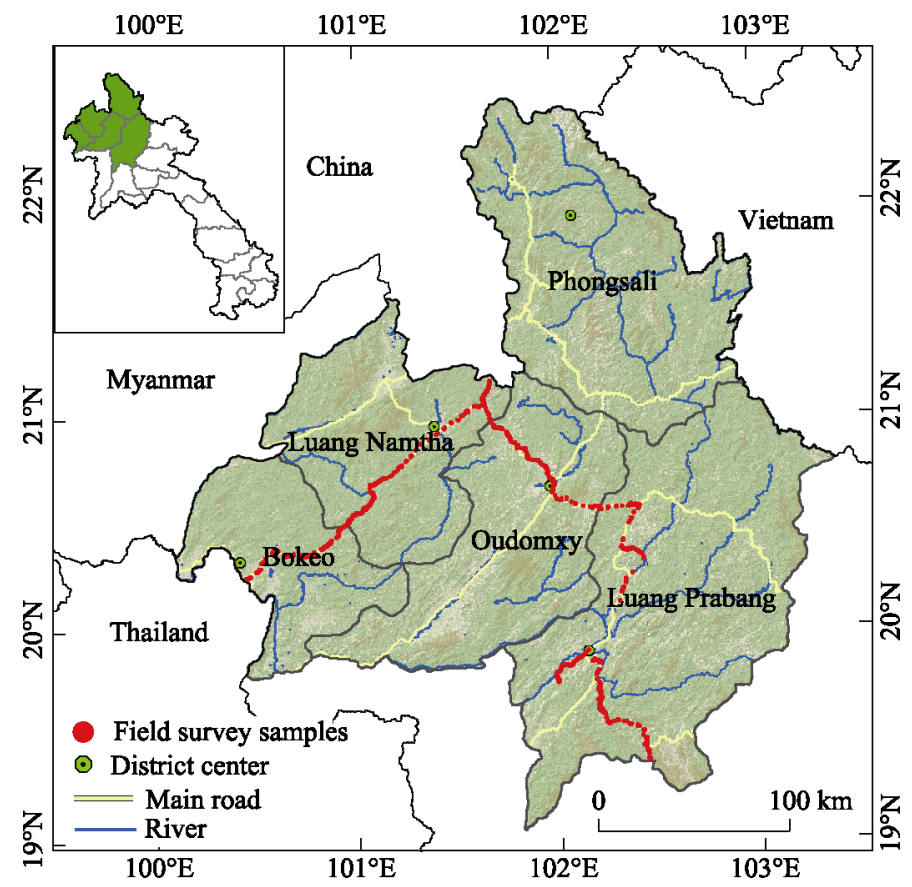

Figure 1 Geographic location of the five provinces in northern Laos showing the field survey conducted from late February to mid-March

\subsection{Data sources and preprocessing}

Landsat TM/ETM+ images (30 m, Table 1) acquired in the dry season around 1990 and dur- 
ing 2000-2011 were obtained from United States Geological Survey (USGS). Imagery in 2008 was not available. All the images had already been geometrically corrected. Considering the ETM+ Scan Line Corrector (SLC) off problem after May 31, 2003, a data-filling method of local histogram matching provided by ENVI was used to fill in the gaps in the Landsat 7 SLC-off data.

The global digital elevation model (GDEM) data with 30-m resolution was obtained from the Computer Network Information Center, Chinese Academy of Sciences. With ArcGIS software, exceptional and missing DEM data values were processed with the Nibble tool and the Raster Calculator. Geographic information on elevation, slope, and aspect were derived from the GDEM data. Field survey samples were acquired in northern Laos from February 24 to March 18, 2013 (Figure 1). Glob-Cover 2009 datasets of Laos with a 300-m resolution developed by the European Space Agency were used as references for remote-sensing interpretation. High-resolution Quickbird images from Google Earth ${ }^{\mathrm{TM}}$ (GE) were used for remote-sensing interpretation and classification validation.

\subsection{Mapping and delineating swidden system and other land use/covers}

To monitor the spatial extent of swidden agriculture and analyze its spatio-temporal changes in the burning and cropping phases, the land-use and land-cover types identified in this study involved swidden agriculture in the burning and cropping phases, permanent farmlands, forest cover, shrubs/grass, water bodies, and built-up land. A decision-tree model was used for land use and land cover classification. Reflectance values of six non-thermal bands of TM/ETM+ imagery, NDVI, and soil brightness (SB) and soil wetness (SW) retrieved from

the Tassel Cap Transformation and Texture index (homogeneity, correlation, entropy, and angular second moment) were calculated to determine the classification parameters. NDVI, $\mathrm{SB}$, and SW were calculated under the ENVI 5.0 platform. The equations used were listed as follows:

$$
\mathrm{NDVI}=\left(\mathrm{TM}_{4}-\mathrm{TM}_{3}\right) /\left(\mathrm{TM}_{4}+\mathrm{TM}_{3}\right)
$$

Bright $=\mathrm{TM}_{1} \times 0.3037+\mathrm{TM}_{2} \times 0.2793+\mathrm{TM}_{3} \times 0.4343+\mathrm{TM}_{4} \times 0.5585+\mathrm{TM}_{5} \times 0.5082+\mathrm{TM}_{7} \times 0.1863$, Moist $=\mathrm{TM}_{1} \times 0.1509+\mathrm{TM}_{2} \times 0.1793+\mathrm{TM}_{3} \times 0.3299+\mathrm{TM}_{4} \times 0.3406+\mathrm{TM}_{5} \times(-0.7112)+\mathrm{TM}_{7} \times(-0.4572)$,

where $\mathrm{TM}_{1}-\mathrm{TM}_{5}$ represent the blue, green, red, near-infrared (NIR), and short-wave infrared (SWIR1) band respectively, and $\mathrm{TM}_{7}$ is the SWIR2 band.

A combination of field data, Quickbird and TM/ETM+ images was used to validate the classification results. Quickbird images from GE were available only in parts of northern Laos. For most historical years, validation data were selected from TM/ETM+ images in the dry season using visual interpretation. In the uplands of northern Laos, as the swidden plots are quite small and the spectral features of burned pixels are different from those of other land-use and land-cover types, selection of burned pixels through visual interpretation of Landsat images with band composition of SWIR1, NIR, and red bands is straightforward. As the burned pixels would be transformed to crop pixels in the subsequent one to three years, burned pixels in earlier years were used to validate crop pixels in later years.

\subsection{Methods for calculating the swidden cycle}

A new method was proposed to calculate the swidden cycle in northern Laos under ArcGIS 10.0. The equation was listed as follows: 
Table 1 Details of Landsat TM/ETM+ imagery used in this study

\begin{tabular}{|c|c|c|c|c|c|c|c|}
\hline Path/Row & Date & Sensors & $\begin{array}{c}\text { Cloud } \\
\text { coverage }(\%)\end{array}$ & Path/Row & Date & Sensors & $\begin{array}{c}\text { Cloud } \\
\text { coverage }(\%)\end{array}$ \\
\hline \multirow{15}{*}{$128 / 46$} & 1989-03-02 & TM & 10 & \multirow{17}{*}{$129 / 45$} & $1989-03-25$ & TM & 10 \\
\hline & 2000-04-01 & ETM+ & 0 & & $2000-03-23$ & ETM+ & 3 \\
\hline & 2001-04-20 & ETM+ & 1 & & 2001-04-19 & $\mathrm{TM}$ & 0 \\
\hline & 2002-04-07 & ETM+ & 0 & & 2002-04-30 & ETM+ & 0 \\
\hline & $2003-03-01$ & TM & 0 & & $2003-02-28$ & ETM+ & 2 \\
\hline & 2004-03-11 & ETM+ & 0 & & 2004-03-10 & $\mathrm{TM}$ & 4 \\
\hline & 2004-03-19 & $\mathrm{TM}$ & 10 & & 2004-04-11 & TM & 9 \\
\hline & $2005-03-06$ & $\mathrm{TM}$ & 8 & & $2005-02-25$ & $\mathrm{TM}$ & 1 \\
\hline & $2006-03-17$ & ETM+ & 4 & & 2006-03-08 & ETM+ & 0 \\
\hline & 2006-04-02 & ETM+ & 0 & & $2006-03-24$ & ETM+ & 0 \\
\hline & 2007-03-04 & ETM+ & 0 & & $2007-02-23$ & ETM+ & 0 \\
\hline & $2007-05-07$ & ETM+ & 20 & & 2007-03-11 & ETM+ & 1 \\
\hline & 2009-02-13 & $\mathrm{TM}$ & 0 & & 2009-02-12 & ETM+ & 2 \\
\hline & $2010-02-16$ & $\mathrm{TM}$ & 63 & & $2009-02-28$ & ETM+ & 36 \\
\hline & 2011-02-11 & ETM+ & 7 & & $2010-02-15$ & ETM+ & 0 \\
\hline \multirow{15}{*}{$129 / 46$} & 1988-03-30 & $\mathrm{TM}$ & 1 & & 2010-03-03 & ETM+ & 0 \\
\hline & $1989-03-25$ & TM & 0 & & 2011-04-15 & TM & 30 \\
\hline & $2000-03-07$ & ETM+ & 0 & \multirow{14}{*}{$129 / 47$} & 1988-03-30 & $\mathrm{TM}$ & 0 \\
\hline & 2001-02-06 & ETM+ & 2 & & $2000-03-07$ & ETM+ & 0 \\
\hline & 2002-02-09 & ETM+ & 2 & & 2001-01-05 & ETM+ & 6 \\
\hline & $2003-02-28$ & ETM+ & 4 & & 2002-02-09 & ETM+ & 0 \\
\hline & 2004-01-30 & ETM+ & 6 & & $2003-02-12$ & ETM+ & 8 \\
\hline & 2004-03-02 & ETM+ & 0 & & 2004-01-30 & ETM+ & 3 \\
\hline & $2005-02-25$ & $\mathrm{TM}$ & 0 & & 2004-03-02 & ETM+ & 0 \\
\hline & $2006-02-28$ & $\mathrm{TM}$ & 0 & & 2005-02-09 & $\mathrm{TM}$ & 0 \\
\hline & $2007-02-23$ & ETM+ & 0 & & $2006-02-28$ & TM & 0 \\
\hline & 2007-03-11 & ETM+ & 0 & & 2007-03-11 & ETM+ & 1 \\
\hline & 2009-01-19 & $\mathrm{TM}$ & 6 & & $2007-03-27$ & ETM+ & 0 \\
\hline & 2010-04-04 & ETM+ & 6 & & 2009-01-19 & TM & 0 \\
\hline & 2011-04-15 & TM & 0 & & $2010-03-03$ & ETM+ & 0 \\
\hline \multirow{15}{*}{$130 / 46$} & 1989-01-11 & TM & 0 & & 2011-04-15 & TM & 2 \\
\hline & $2000-03-14$ & ETM+ & 0 & \multirow{14}{*}{$130 / 45$} & 1989-01-11 & TM & 5 \\
\hline & 2001-04-18 & ETM+ & 0 & & $1989-01-27$ & TM & 20 \\
\hline & $2002-04-21$ & ETM+ & 0 & & $2000-03-14$ & ETM+ & 2 \\
\hline & 2003-04-18 & ETM+ & 0 & & 2001-04-10 & $\mathrm{TM}$ & 0 \\
\hline & $2004-03-25$ & ETM+ & 0 & & $2002-04-21$ & ETM+ & 0 \\
\hline & 2004-04-26 & ETM+ & 3 & & 2003-04-08 & ETM+ & 0 \\
\hline & $2005-02-16$ & $\mathrm{TM}$ & 0 & & 2004-03-01 & TM & 0 \\
\hline & 2006-11-10 & ETM+ & 9 & & $2005-02-16$ & TM & 0 \\
\hline & $2006-11-26$ & ETM+ & 2 & & $2007-03-26$ & $\mathrm{TM}$ & 0 \\
\hline & $2007-03-26$ & $\mathrm{TM}$ & 0 & & 2009-03-07 & ETM+ & 0 \\
\hline & 2009-03-07 & ETM+ & 0 & & $2009-03-23$ & ETM+ & 0 \\
\hline & 2009-04-24 & ETM+ & 0 & & 2010-02-14 & $\mathrm{TM}$ & 0 \\
\hline & 2010-04-11 & ETM+ & 0 & & $2011-02-25$ & ETM+ & 0 \\
\hline & 2011-04-22 & $\mathrm{TM}$ & 3 & & 2011-04-22 & $\mathrm{TM}$ & 10 \\
\hline
\end{tabular}




$$
L_{n}=B_{k}+B_{k+n}-\sum_{i=1}^{n-1} L_{i}
$$

where $L_{n}$ is the raster data for burned pixels with swidden cycle of $n$ years. $k$ is a year constant. As the swidden cycles of the burned pixels in 2000, 2003, and 2007 were analyzed, $k$ is set as 2000, 2003 and 2007 correspondingly. $n$ refers to the length of swidden cycle. As the study period is from 2000 to 2011 , the value of $n$ is set from 1 to 11 years. $B_{k}$ refers to the raster data for burned pixels in year $k$, and $B_{k+n}$ refers to the raster data for burned pixels in year $k+n$. The plus symbol between $B_{k}$ and $B_{k+n}$ means that the spatial intersection should be taken. $i$ is a variable ranged from 1 to $(n-1) . \quad \sum_{i=1}^{n-1} L_{i}$ is the burned pixels with swidden cycle from 1 to $(n-1)$ years. When $n$ is set as $2, \sum_{i=1}^{n-1} L_{i}$ is the raster data for burned pixels with swidden cycle of 1 year. When $n$ is set as $1, \sum_{i=1}^{n-1} L_{i}$ should be ignored.

\subsection{Methods for calculating the frequency of swidden use}

The burned pixels detected in 2000 were compared with their counterparts in the following years (2001-2011) to investigate the frequency of swidden use using time-series Landsat-based NDVI data (Figure 2). First, the burned pixels in each year from 2000 to 2011 were detected. Then the intersections of burned pixels in 2000 and those in subsequent years from 2001 to 2011 were extracted. Time-series NDVIs of these pixels were determined for the whole period from 2001 to 2011. Generally, the NDVI of burned pixels dropped sharply to a low level, generally zero or negative, and then increased from a moderate to high value before slashing and burning. Therefore, by counting the number of times when the NDVI of burned pixels fell below zero, the frequency of swidden use during 2001-2011 was calculated.

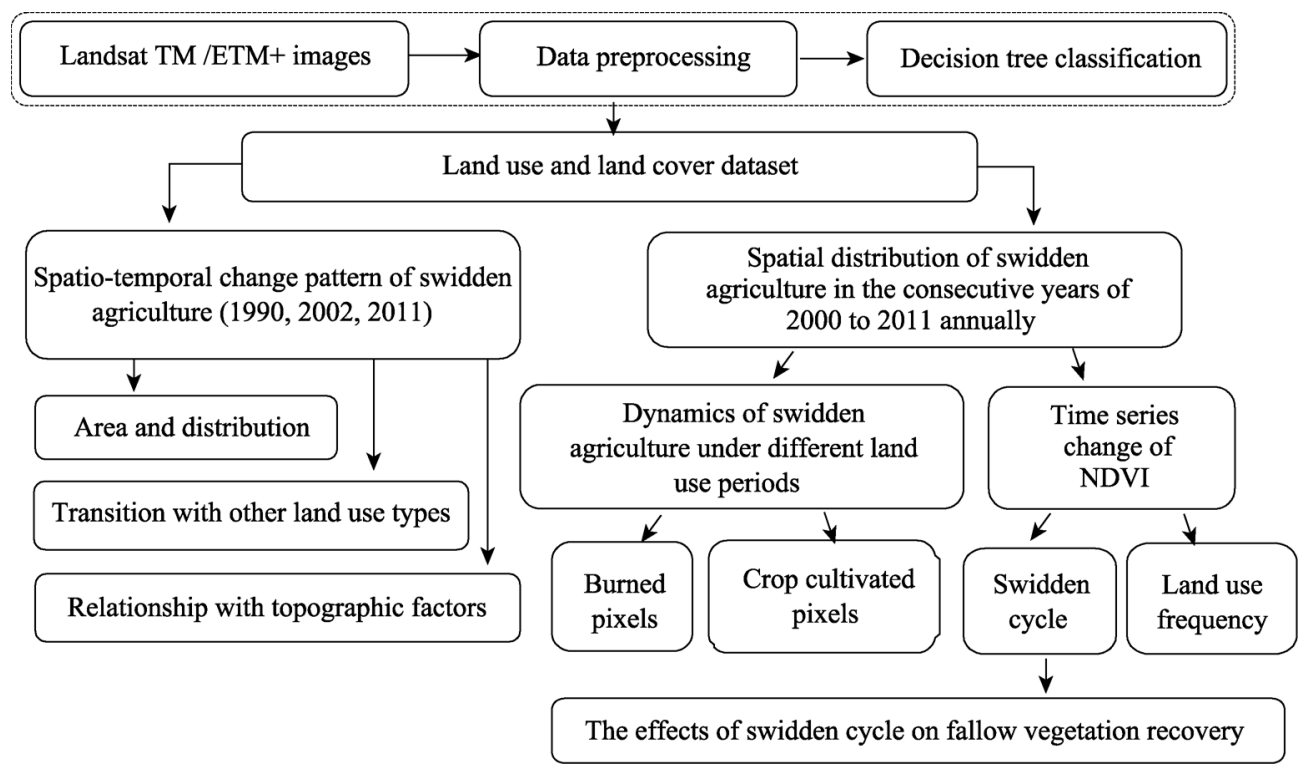

Figure 2 Workflow for monitoring the spatio-temporal dynamics of swidden agriculture and its effects on fallow vegetation recovery 


\section{Spatial and temporal changes in swidden agriculture from 1990 to 2011}

\subsection{Area and distribution of swidden agriculture}

The spatial extents of swidden farming in northern Laos in 1990, 2002, and 2011 were delineated in Figure 3. During 1990-2011, the area of swidden agriculture increased by $54.98 \%$, from $1.54 \times 10^{5}$ ha to $2.38 \times 10^{5}$ ha. From 1990 to 2002 , the area of swidden cultivation increased by $23.94 \%$, and the proportion within the study area increased from $2.41 \%$ to $2.99 \%$. From 2002 to 2011 , the area of swidden agriculture increased by $25.05 \%$, and the proportion within the study area increased from $2.99 \%$ to $3.73 \%$. In the five provinces of northern Laos, swidden farming in Bokeo experienced continuous increase of nearly six
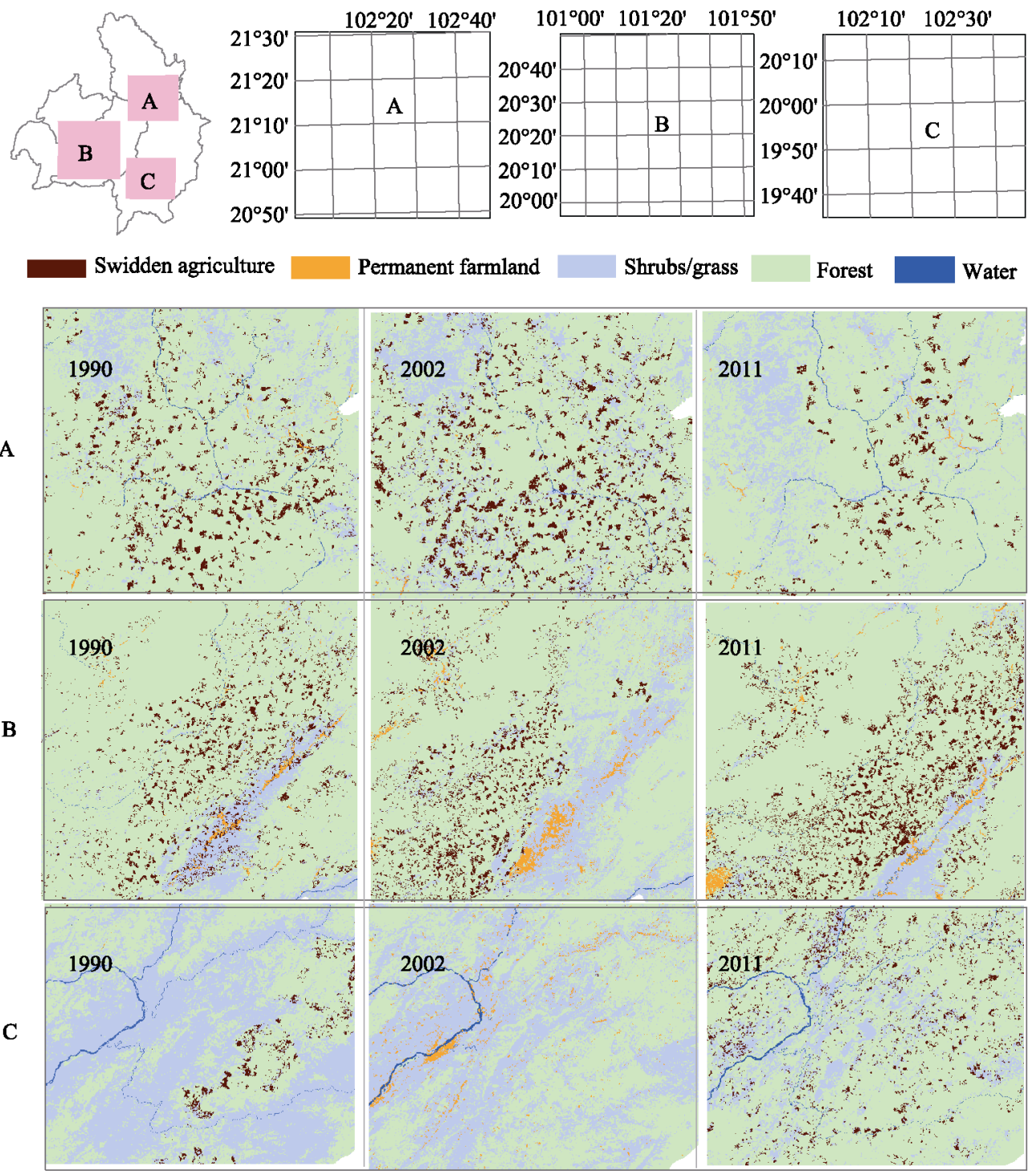

Figure 3 Spatial distribution of swidden agriculture and other land use/cover types for regions A, B, and C in northern Laos 
times from 1990 to 2011 in the area spanning from the eastern part bordering Oudomxay and Luang Namtha to the southern parts near the Mekong River. During the same period, the area of swidden cultivation declined by $61.06 \%$ in Phongsali and was distributed mainly in the southern region. As fallow vegetation was not recovered and could not be used for swidden farming until 2009, the area of swidden agriculture in Luang Prabang fluctuated, with a slight decrease from 1990 to 2002 and an intense increase from 2002 to 2011, which amounts to a general increase of nearly 1.5 times. Due to the cropping-fallow transition, the area of swidden agriculture in Oudomxay fluctuated, with a slight decrease from 1990 to 2002 and an increase from 2002 to 2011; it generally increased by $29.12 \%$ in the western region bordering Luang Namtha and Bokeo. The area of swidden agriculture in Luang Namtha also fluctuated, with an increase from 1990 to 2002 and a decrease from 2002 to 2011, and generally increased by $52.45 \%$ in northern and central regions (Figure 4a).

The relationships between the changes of swidden agriculture and topographic factors (elevation, slope, and aspect) in northern Laos were analyzed. The range of elevation was divided into six categories: 0-300 m, 300-500 m, 500-800 m, 800-1000 m, 1000-1500 m, and 1500-2000 $\mathrm{m}$. The range of slopes was divided into four categories: $<10^{\circ}, 10^{\circ}-20^{\circ}, 20^{\circ}-30^{\circ}$ and $>30^{\circ}$. The range of aspects was divided into eight types: north $(\mathrm{N})$, northeast $(\mathrm{NE})$, east (E), southwest (SE), south (S), southwest (SW), west (W), and northwest (NW). The results are shown in Figures $4 \mathrm{~b}, 4 \mathrm{c}$, and $4 \mathrm{~d}$. Firstly, swidden cultivation was predominantly distributed at elevations of 500-800 m, 800-1000 m, and 1000-1500 m. From 1990 to 2011, the area under swidden farming increased by $60.87 \%, 25.20 \%$, and $19.43 \%$ respectively at elevations of 500-800 m, 300-500 m, and 800-1000 m, whereas decreases occurred mainly at elevations above $1000 \mathrm{~m}$. Secondly, most swidden systems in northern Laos were distributed on slopes of $10^{\circ}-20^{\circ}$ and $20^{\circ}-30^{\circ}$. From 1990 to 2011 , the area of swidden farming increased by $45.16 \%$ and $29.70 \%$ respectively on slopes of $10^{\circ}-20^{\circ}$ and $20^{\circ}-30^{\circ}$. There was a $19.35 \%$ increase in swidden agriculture on slopes of $<10^{\circ}$ and a $5.79 \%$ increase on slopes of $>30^{\circ}$. Finally, there were approximately equal proportions of swidden cultivation for all aspects. This indicates that swidden use in northern Laos is not restricted by aspect.

Land-use transformations of swidden cultivation in northern Laos during 1990-2011 are shown in Figures 4e and 4f. Most transformations involved conversions of swidden agricultural land to or from forest land. From 1990 to 2011, 79.57\% of swidden agricultural land was transformed to forest cover and $20.25 \%$ to shrubland. During the same period, $84.19 \%$ of forest cover and $14.74 \%$ of shrubland were transformed to swidden agriculture. During 1990-2002, approximately 41,363 ha and 4,007 ha of swidden agricultural land were converted to forest land, shrubland, and permanent agriculture, accounting for $68.47 \%, 28.74 \%$, and $2.78 \%$ of the decrease in swidden land. Meanwhile, approximately 161,430 ha, 18,037 ha, and 1264 ha of forest land, shrubland, and permanent agricultural land were transformed into swidden cultivation, accounting for $89.32 \%, 9.98 \%$, and $0.7 \%$ of the increase in swidden agriculture. During 2002-2011, approximately 141,555 ha, 29,720 ha, and 2473 ha of swidden cultivation were changed into forest land, shrubland, and permanent agriculture, accounting for $81.47 \%, 17.11 \%$, and $1.42 \%$ of the decrease in swidden agriculture. Meanwhile, approximately 146,165 ha, 69,889 ha, and 5,457 ha of forest land, shrubland, and 
permanent agricultural land were transformed to swidden cultivation, accounting for $65.99 \%$, $31.55 \%$, and $2.46 \%$ of the increase in swidden agriculture.

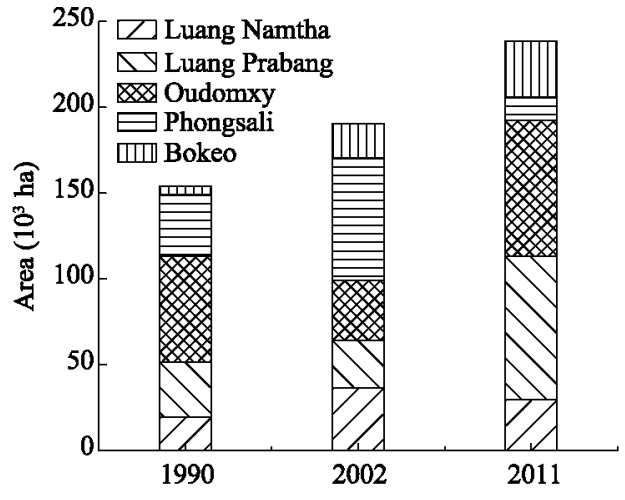

(a) The area of swidden cultivation

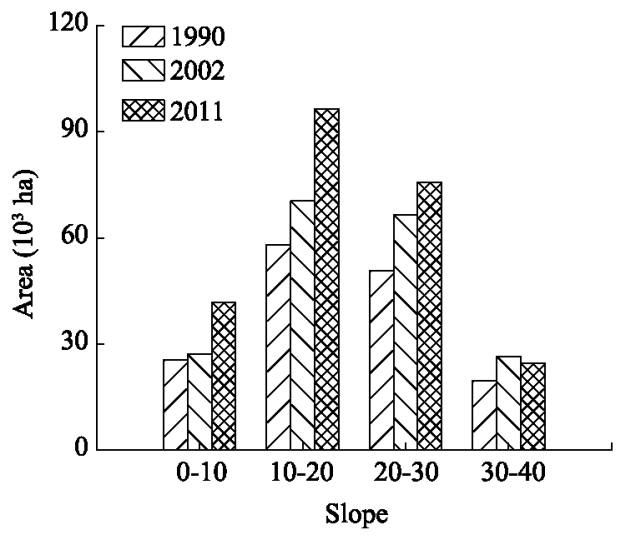

(c) Swidden cultivations distributed in different slopes

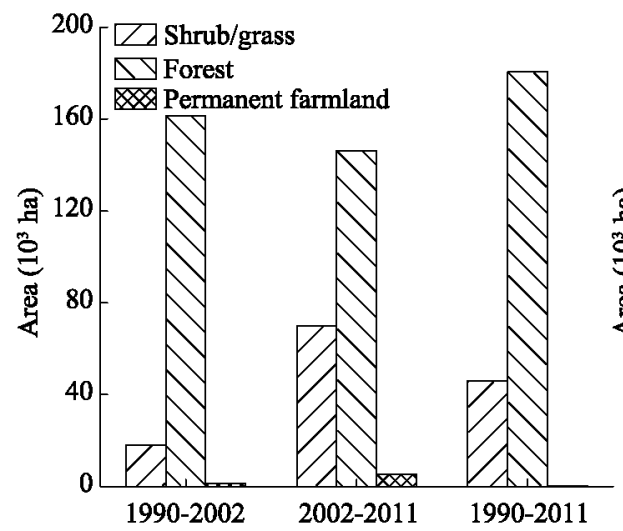

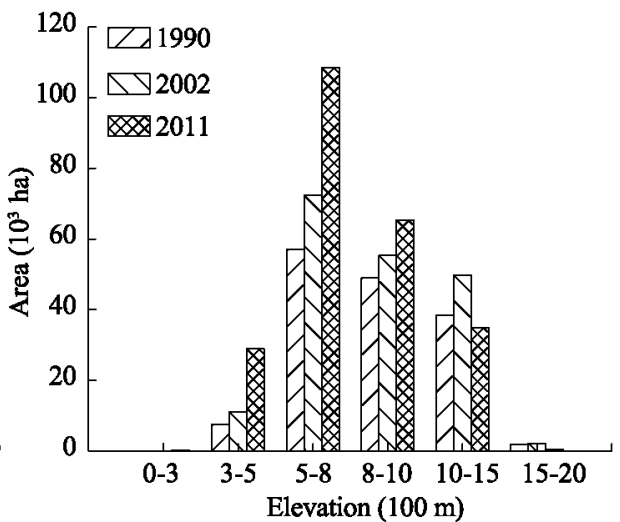

(b) Swidden cultivations distributed in different elevations

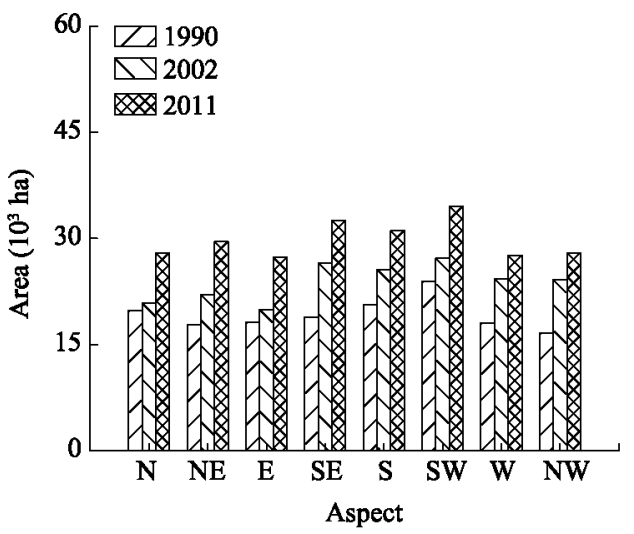

(d) Swidden cultivations distributed in different aspects

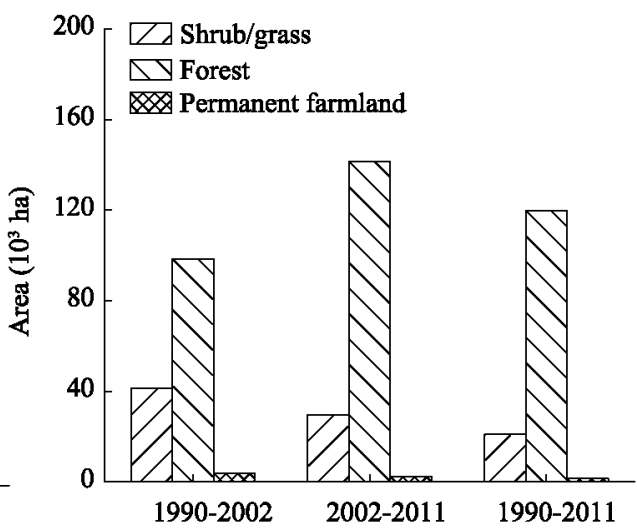

(e) Other land use/covers transformed to swidden agriculture (f) Swidden agriculture transformed to other land use/covers

Figure 4 Spatio-temporal dynamics of swidden agriculture in northern Laos from1990 to 2011

\subsection{Dynamics of burned land and cropland under swidden agriculture}

The spatial distribution of swidden system in the burning and cropping phases (hereafter 
referred to as burned land/pixels and cropland/crop pixels) by year from 2000 to 2011 are shown in Figure 5. Due to the lack of available imagery in 2008, burned pixels in 2008 were replaced with crop pixels in 2009 and 2010, whereas crop pixels in 2008 were replaced with burned pixels in 2006 and 2007. The area of burned land and cropland both fluctuated (see Figure 6). The area of burned land reached maxima of $12.99 \times 10^{4}$ ha, $10.01 \times 10^{4}$ ha, $7.06 \times 10^{4}$ ha, and $17.96 \times 10^{4}$ ha respectively in $2002,2004,2007$, and 2011 . The time interval between two successive maxima was approximately one to three years. The area of burned land reached minima of $5.31 \times 10^{4}$ ha, $2.98 \times 10^{4}$ ha, and $3.72 \times 10^{4}$ ha respectively in 2003,2005 , and 2008. The time interval between two successive minima was approximately one to three years. Cropland area reached maxima in 2003, 2005, and 2008, when the area of burned land was at a minimum. This illustrates that the overall area of swidden agriculture remained stable over the study period. Cropland area reached or nearly reached maxima in 2002, 2007, and 2011, when the area of burned land also reached a maximum. This indicates that the entire area under swidden cultivation expanded in these years. Cropland area reached minima in 2004, 2006, and 2009, when the area of burned land reached a maximum or continued to increase. This indicates that the overall area of swidden agriculture remained stable in these years. The times when cropland reached a minimum $(2004,2006,2009)$ lagged one year behind the times when burned land reached a minimum (2003, 2005, 2008), which was consistent with the swidden practice of converting burned land to cropland in the following year accordingly.
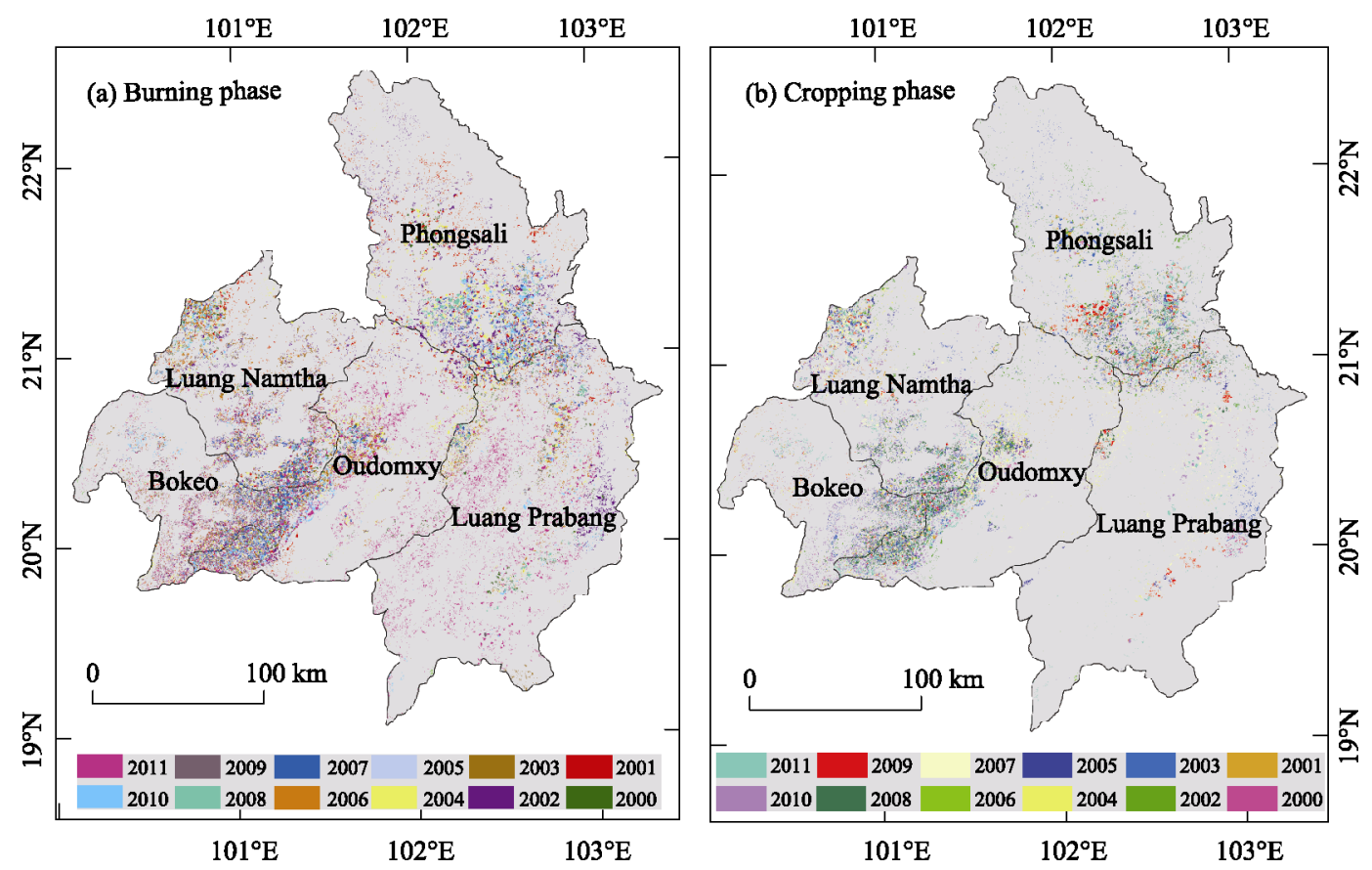

Figure 5 Spatial distribution of swidden cultivation in the burning and cropping phases in northern Laos during 2000-2011 

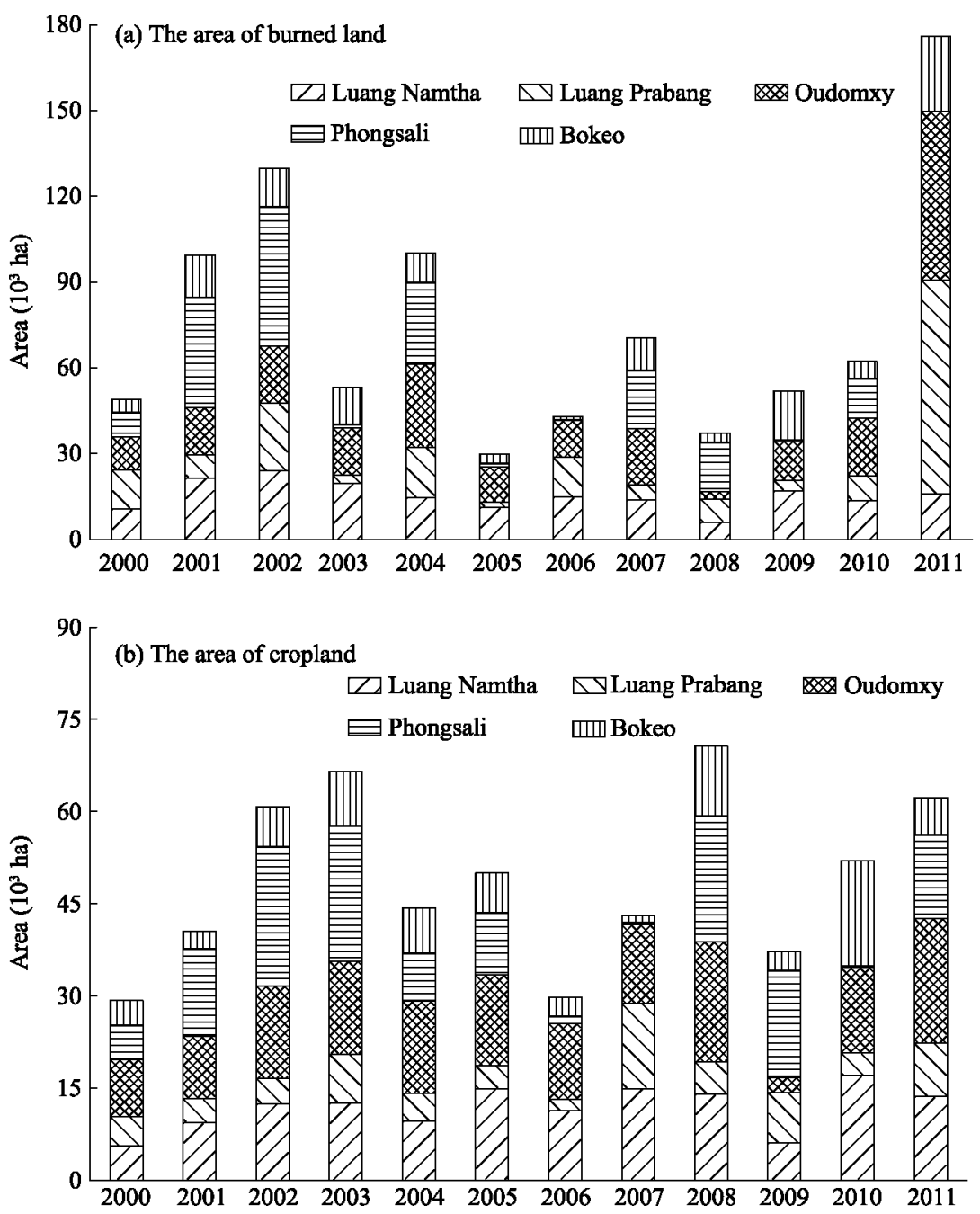

Figure 6 Area of swidden cultivation in the burning and cropping phases in northern Laos from 2000 to 2011

\section{Changes in the intensity of swidden agriculture from 2000 to 2011}

\subsection{Changes in the frequency of swidden use based on time-series NDVI}

The intersections of burned pixels in 2000 and their counterparts in subsequent years from 2001 to 2011 were extracted. Time-series NDVI of these pixels were extracted for the whole period from 2001 to 2011 (Figure 7). For the intersection of burned pixels in 2000 and those in 2011, the NDVI of burned pixels fell below zero from a relatively high value about three times during 2001-2011. This indicates that the frequency of swidden use was four times (once in 2000, and three times in 2004, 2007, and 2011). For the intersection of burned pixels in 2000 and those in 2010, the NDVI of burned pixels fell below zero from a relatively high value about twice during 2001-2011. This indicated that the frequency of swidden use was three times (once in 2000, and twice in 2004 and 2010). Similarly, for the intersection of burned pixels in 2000 and that in other years, the frequencies of swidden use were 


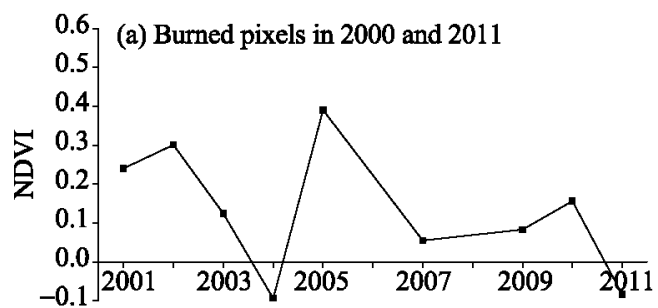

0.6 (c) Burned pixels in 2000 and 2009

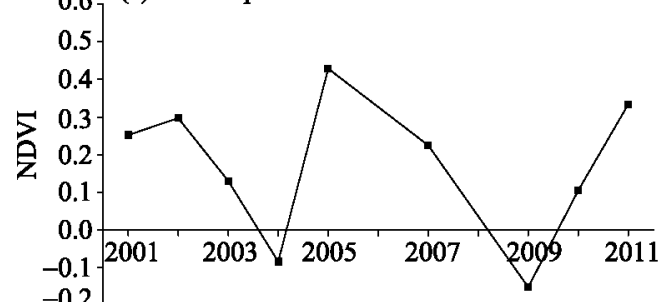

(e) Burned pixels in 2000 and 2007

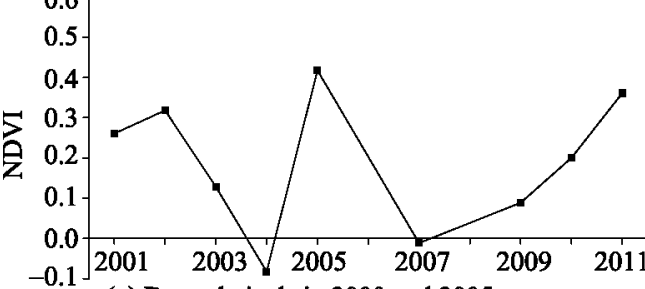

0.6 (g) Burned pixels in 2000 and 2005
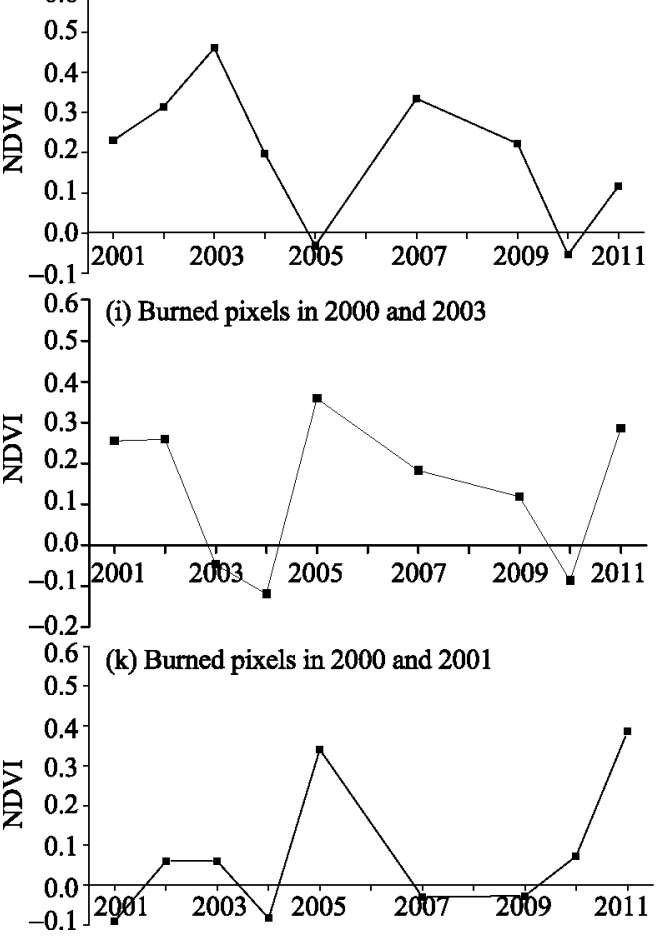

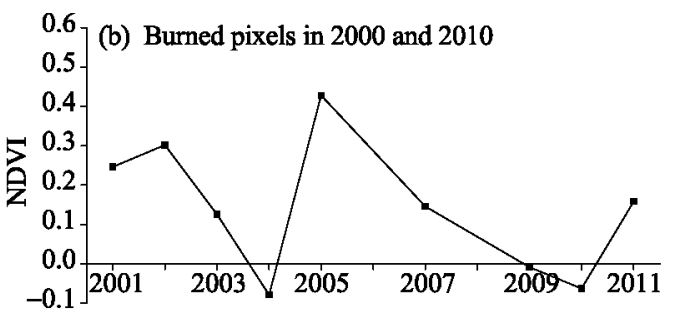

(d) Burned pixels in 2000 and 2008
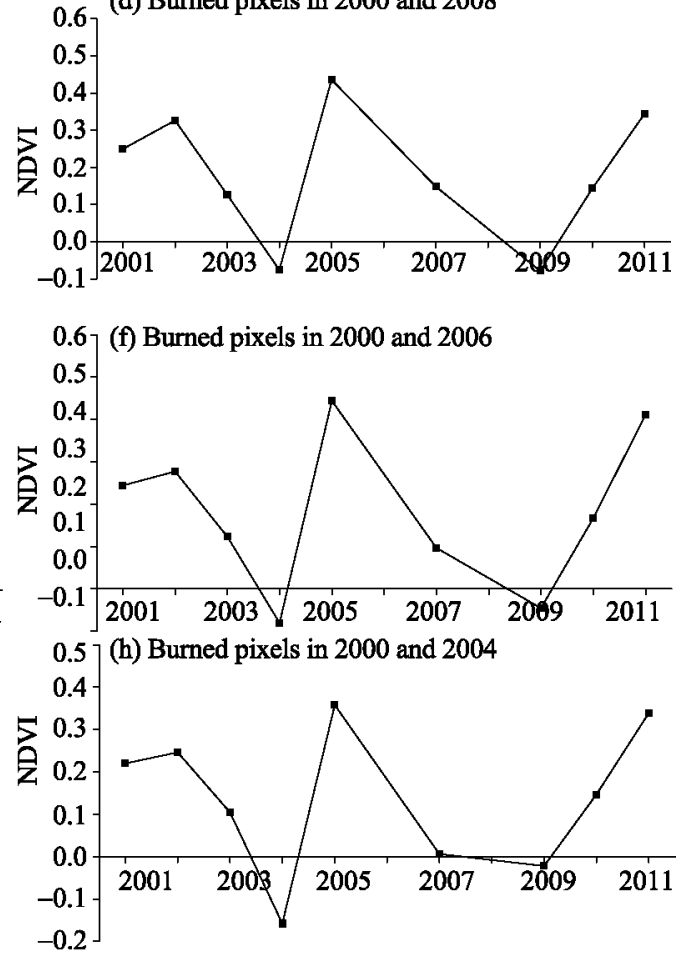

0.6 (j) Burned pixels in 2000 and 2002

0.5

0.4

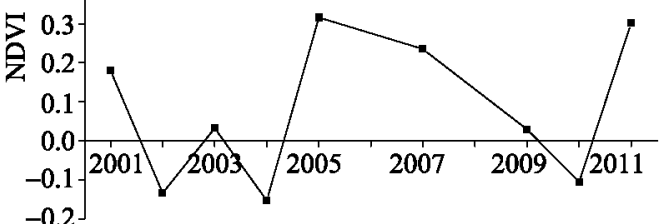

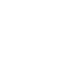


calculated accordingly. Generally, the frequency of swidden use in northern Laos was about three or four times during 2000-2011. The interval between two successive episodes of swidden use ranged from one to seven years. Most burned lands in the swidden system in 2000 were reused in 2004 and again around 2009.

\subsection{Changes of the swidden cycle in 2000, 2003, and 2007}

To investigate the changes of swidden cycle between 2000 and 2011, the swidden cycles of the burned pixels in 2000, 2003, and 2007 were analyzed (Figure 8). The swidden cycles of burned pixels in 2000 were divided into four categories: 1-4 years, 5-8 years, 9-11 years, and $\geq 12$ years. The swidden cycles of burned pixels in 2003 were divided into three categories: $1-4$ years, $5-8$ years, and $\geq 9$ years. The swidden cycles of burned pixels in 2007 were divided into two categories: $1-4$ years and $\geq 5$ years. In $2000,4.90 \%$ of burned pixels had swidden cycles of 1 to 4 years, $17.37 \%$ of burned pixels had swidden cycles of 5 to 8 years, $13.34 \%$ of burned pixels had swidden cycles of 9 to 11 years, and $64.72 \%$ of burned pixels had swidden cycles of more than 12 years (including 12 years). In 2003, 3.89\% of burned pixels had swidden cycles of 1 to 4 years, $20.41 \%$ of burned pixels had swidden cycles of 5 to 8 years, and $75.70 \%$ of burned pixels had swidden cycles of more than 9 years (including 9 years). The proportion of land with swidden cycle shorter than 9 years increased from 2000 to 2003 . The number of burned pixels with swidden cycles of 1 to 4 years increased by $4.63 \%$ from 2000 to 2003 . Generally, the swidden cycle in northern Laos was shorter after 2000, but the change was slight.

(a) 2000

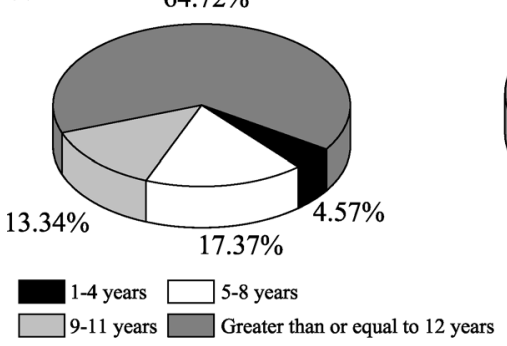

(b) 2003

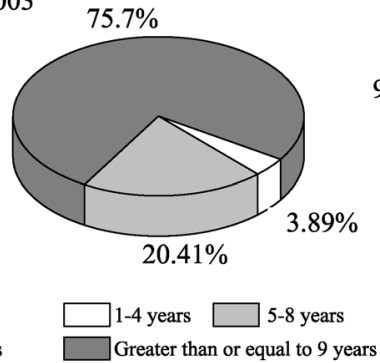

(c) 2007

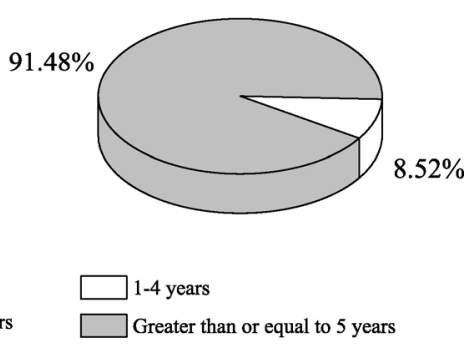

Figure 8 Swidden cycle and related swidden farming practice in northern Laos in 2000, 2003, and 2007

\subsection{Effects of the swidden cycle on fallow vegetation recovery}

As the swidden cycle ranged from 1 to 11 years, fallow vegetation succession processes were studied based on Landsat-derived NDVI (see Table 2). The NDVI of fallow vegetation increased from 0.20 to 0.63 as the swidden cycle increased from 2 to 11 years. As the swidden cycle became longer, fallow vegetation recovery improved, with higher NDVI values. The linear relationship between them was expressed by $Y=0.0476 X+0.1769$, with a correlation coefficient of 0.9698 (Figure 9). In addition, the average NDVI of forest lands in northern Laos was calculated. The results proved that as the swidden cycle lengthened beyond eight years, the NDVI of fallow vegetation (0.55) approximately reached the average NDVI of forest cover (0.56). As the swidden cycle lengthened beyond 10 years, the NDVI of fallow vegetation (0.59) became higher than the average level in forests. 
Table 2 Fallow vegetation recovery process with increasing swidden cycle based on time-series Landsat NDVI

\begin{tabular}{|c|c|c|c|c|c|c|c|c|c|c|c|}
\hline \multirow{2}{*}{$\begin{array}{c}\text { Swidden } \\
\text { cycle (years) }\end{array}$} & \multicolumn{11}{|c|}{ NDVI of fallow vegetation } \\
\hline & 2001 & 2002 & 2003 & 2004 & 2005 & 2006 & 2007 & 2008 & 2009 & 2010 & 2011 \\
\hline 11 & 0.2453 & 0.3042 & 0.3252 & 0.3561 & 0.3903 & - & 0.4734 & - & 0.5482 & 0.6257 & 0.0604 \\
\hline 10 & 0.2495 & 0.3228 & 0.3241 & 0.3786 & 0.4176 & - & 0.5216 & - & 0.5913 & -0.6381 & \\
\hline 9 & 0.2539 & 0.3030 & 0.3332 & 0.3807 & 0.4322 & - & 0.5326 & - & -0.5542 & & \\
\hline 8 & 0.2499 & 0.3319 & 0.3285 & 0.3734 & 0.4386 & - & 0.5546 & - & & & \\
\hline 7 & 0.2567 & 0.3210 & 0.3463 & 0.3612 & 0.4165 & - & -0.2751 & & & & \\
\hline 6 & 0.2479 & 0.2845 & 0.3247 & 0.3766 & 0.4484 & - & & & & & \\
\hline 5 & 0.2470 & 0.2816 & 0.3202 & 0.3603 & -0.0726 & & & & & & \\
\hline 4 & 0.2380 & 0.2484 & 0.3045 & -0.1569 & & & & & & & \\
\hline 3 & 0.2745 & 0.2863 & -0.0445 & & & & & & & & \\
\hline 2 & 0.1968 & -0.1268 & & & & & & & & & \\
\hline 1 & -0.0905 & & & & & & & & & & \\
\hline
\end{tabular}

\section{Conclusions}

This paper analyzed the spatio-temporal dynamics of swidden agriculture in the five provinces of northern Laos from the four perspectives of area, spatial distribution, relationship with topographic factors, and land-use transformation to and from other land-use or land-cover types. It also analyzed the intensity of swidden use and the effects of the swidden cycle on fallow forest recovery. Some insightful conclusions

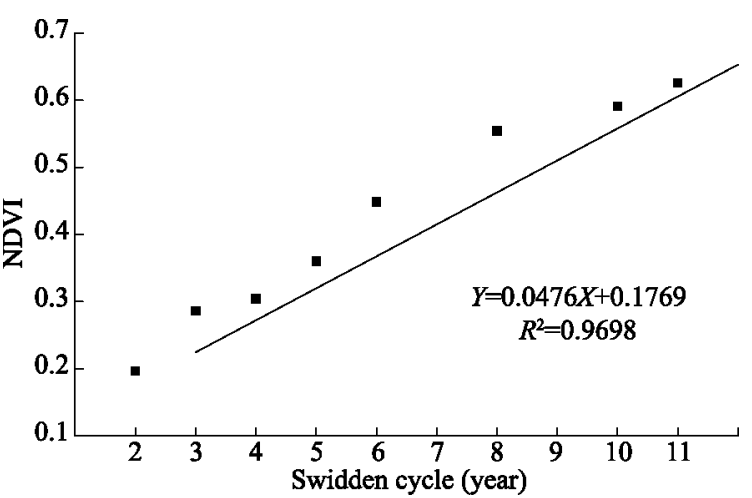

Figure 9 Relationship of fallow vegetation recovery and swidden cycle in northern Laos can be drawn as follows:

(1) From 1990 to 2011, the area of swidden agriculture in northern Laos increased by $54.98 \%$, from $1.54 \times 10^{5}$ ha to $2.38 \times 10^{5}$ ha. From 1990 to 2002 , the area of swidden cultivation increased by $23.94 \%$; these increases were distributed mainly in southwestern Bokeo, central Luang Namtha, and northern and central Phongsali. From 2002 to 2011, the area of swidden agriculture increased by $25.05 \%$, and the increases were distributed mainly in southern Bokeo, Luang Prabang, and Oudomxay. Swidden cultivation was predominantly distributed at elevations of 500-800 m, 800-1000 m, and 1000-1500 m and on slopes of $10^{\circ}-20^{\circ}$ and $20^{\circ}-30^{\circ}$ in northern Laos. There were approximately equal proportions of swidden cultivation distributed in all aspects. More than $80 \%$ of swidden agriculture was transformed to or from forest land.

(2) The areas of burned land and cropland both fluctuated during 2000-2011. Cropland area reached maxima in 2003, 2005, and 2008, when the area of burned land reached a minimum. Cropland area reached or nearly reached maxima in 2002, 2007, and 2011, when 
the area of burned land also reached a maximum. Cropland area reached minima 2004, 2006, and 2009, when the area of burned land reached a maximum or continued to increase.

(3) The frequency of swidden use in northern Laos was approximately three or four times during 2000-2011. The intervals between two successive swidden uses ranged from one to seven years. Most burned land in the swidden system in 2000 was reused in 2004 and around 2009. The swidden cycle in northern Laos became shorter after 2000, but the change was slight. As the swidden cycle became longer, fallow vegetation recovery improved, with higher NDVI values. The correlation coefficient between the two was 0.97 . As the swidden cycle extended beyond eight years, the NDVI of fallow vegetation (0.55) approximately reached the average NDVI of forest cover (0.56). As the swidden cycle extended beyond ten years, the NDVI of fallow vegetation (0.59) became higher than the average level of forests.

In this study, we have delineated the swidden system in northern Laos at regional scale using Landsat TM/ETM+ imagery and proposed a new method of calculating the intensity of swidden use in relation to the swidden cycle and swidden frequency. The results and conclusions may contribute to the implementation of the REDD+ framework and the understanding of land use/cover changes (LUCC) in MMSEA. Due to the limited availability of long-term satellite imagery, the study duration of swidden intensity was limited to a period of only 11 years (2000-2011). A longer time-series analysis will be more helpful in fully exploring the swidden intensity. In the future, further studies of the driving factors of change in swidden agriculture and the related socio-economic and environmental consequences in tropical uplands will be required.

\section{References}

Achard F, Eva H D, Stibig H J et al., 2002. Determination of deforestation rates of the world's humid tropical forests. Science, 297(5583): 999-1002.

Bruun T B, de Neergaard A, Lawrence D et al., 2009. Environmental consequences of the demise in swidden cultivation in Southeast Asia: Carbon storage and soil quality. Human Ecology, 37(3): 375-388.

Chowdary V M, Yasuyuki K, Tateishi R, 2012. Monitoring of spatio-temporal land cover changes in part of Oudomxay province, northern mountainous region of Laos using remote sensing. Asian Journal of Geoinformatics, 12(3): 17-28.

Cramb R A, Colfer C J P, Dressler W et al., 2009. Swidden transformations and rural livelihoods in Southeast Asia. Human Ecology, 37(3): 323-346.

Coomes O T, Grimard F, Burt G J, 2000. Tropical forests and shifting cultivation: Secondary forest fallow dynamics among traditional farmers of the Peruvian Amazon. Ecological Economics, 32(1): 109-124.

Dwivedi R S, Ravi Sankar T, 1991. Monitoring shifting cultivation using space-borne multispectral and multitemporal data. International Journal of Remote Sensing, 12(3): 427-433.

Fox J, 2000. How blaming 'slash and burn' farmers is deforesting mainland Southeast Asia, 47: 1-8. http://hdl.handle.net/10125/3832.

Fox J, Castella J C, Ziegler A D, 2014. Swidden, rubber and carbon: Can REDD+ work for people and the environment in Montane Mainland Southeast Asia? Global Environmental Change, 29: 318-326.

Hett C, Castella J C, Heinimann A et al., 2012. A landscape mosaics approach for characterizing swidden systems from a REDD+ perspective. Applied Geography, 32(2): 608-618.

Hurni K, Hett C, Heinimann A et al., 2013. Dynamics of shifting cultivation landscapes in northern Lao PDR between 2000 and 2009 based on an analysis of MODIS time series and Landsat images. Human Ecology, 41(1): 21-36. 
Leisz S J, Rasmussen M S, 2012. Mapping fallow lands in Vietnam's north-central mountains using yearly Landsat imagery and a land-cover succession model. International Journal of Remote Sensing, 33(20): 6281-6303.

Li P, Feng Z, Jiang L et al., 2014. A review of swidden agriculture in Southeast Asia. Remote Sensing, 6: 1654-1683.

Mertz O, 2009. Trends in shifting cultivation and the REDD mechanism. Current Opinion in Environmental Sustainability, 1(2): 156-160.

Mertz O, Padoch C, Fox J et al., 2009. Swidden changes in Southeast Asia: Understanding causes and consequences. Human Ecology, 37: 259-264.

Mertz O, Wadley R L, Nielsen U et al., 2008. A fresh look at shifting cultivation: Fallow length an uncertain indicator of productivity. Agricultural Systems, 96(1-3): 75-84.

Nakano K, 1978. An ecological study of swidden agriculture at a village in northern Thailand. Southeast Asian Studies, 16(3): 411-446.

Padoch C, Coffey K, Mertz O et al., 2007. The demise of swidden in Southeast Asia? Local realities and regional ambiguities. Geografisk Tidsskrift, 107(1): 29-41.

Padoch C, Pinedo-Vasquez M, 2010. Saving slash-and-burn to save biodiversity. Biotropica, 42(5): 550-552.

Rasul G, Thapa G B, 2003. Shifting cultivation in the mountains of South and Southeast Asia: Regional patterns and factors influencing the change. Land Degradation \& Development, 14(5): 495-508.

Rerkasem K, Lawrence D, Padoch C et al., 2009. Consequences of swidden transitions for crop and fallow biodiversity in Southeast Asia. Human Ecology, 37(3): 347-360.

Roder W, Phengchanh S, Maniphone S, 1997. Dynamics of soil and vegetation during crop and fallow period in slash-and-burn fields of northern Laos. Geoderma, 76(1): 131-144.

Roy P S, Kaul R N, Sharma Roy M R et al., 1985. Forest-type stratification and delineation of shifting cultivation areas in the eastern part of Arunachal Pradesh using LANDSAT MSS data. International Journal of Remote Sensing, 6(3/4): 411-418.

Schmidt Vogt D. Swidden Farming and Fallow Vegetation in Northern Thailand. Franz Steiner, 1999.

Schmidt-Vogt D, Leisz S J, Mertz O et al., 2009. An assessment of trends in the extent of swidden in Southeast Asia. Human Ecology, 37(3): 269-280.

Schuck E C, Nganje W, Yantio D, 2002. The role of land tenure and extension education in the adoption of slash and burn agriculture. Ecological Economics, 43(1): 61-70.

Siren A H, Brondizio E S, 2009. Detecting subtle land use change in tropical forests. Applied Geography, 29(2): 201-211.

Sovu, Tigabu M, Savadogo P et al., 2009. Recovery of secondary forests on swidden cultivation fallows in Laos. Forest ecology and management, 258(12): 2666-2675.

Stibig H J, Belward A S, Roy P S et al., 2007. A land-cover map for South and Southeast Asia derived from SPOT-VEGETATION data. Journal of Biogeography, 34(4): 625-637. 